\title{
Serum Ceruloplasmin in Mice with Ehrlich Ascites Carcinoma
}

High values of serum ceruloplasmin were reported by several authors in human patients with malignant neoplasms. Sullivan and HART ${ }^{1}$ observed this increase of ceruloplasmin in sera of patients with metastatic carcinoma. These findings were confirmed by PINEDA, RAVIN and RUTENBURG ${ }^{2}$ describing high levels of the serum oxidase in human cases with hepatic metastasis and malignant bile duct obstruction. $\mathrm{NEISH}^{3}$ reported in rat liver azo dye carcinogenesis, an initial inhibition of serum ceruloplasmin followed by a rise to normal levels in spite of the development of the tumors (cholangiocarcinomata). Thomas and Constantinescu 4 , Thomas, Olinescu and Constantinescu ${ }^{5}$ working with rats with Jensen carcinoma and $\mathrm{O}-\mathrm{Ya}$ tumor, respectively, obtained significant elevations of serum ceruloplasmin. Our studies ${ }^{6}$ in rats with a transplantable fibrosarcoma showed that the neoplastic process is accompanied by very high values of serum ceruloplasmin activity only comparable to those obtained in acute inflammation produced by i.m. administration of turpentine oil.

The Ehrlich ascites tumor is widely used in biochemical investigations. However, serial data on serum ceruloplasmin activity in mice bearing this important kind of carcinoma are lacking. The present paper will describe the results obtained on this subject.

Material and methods. Male Swiss mice $(25 \mathrm{~g}$ mean body weight) have been used throughout all experiments; they received ad libitum a standard balanced diet and water. A group of 16 mice was used as normal noninoculated controls. The other mice used were injected, by i.p. route, with a clear non-hemorragic cell suspension of Ehrlich ascites carcinoma removed from a mouse treated similarly 10 days before. The ascitic fluid diluted in physiological saline at the concentration of $2.0 \times 10^{8}$ Ehrlich cells $/ 0.1 \mathrm{ml}$ was immediately administered, at this dose level, to the recipient animals.

Mice were killed by decapitation at 4, 7, 10 and 14 days after the inoculations, blood samples were collected and

Serum ceruloplasmin in mice bearing Ehrlich ascites carcinoma

\begin{tabular}{lcll}
\hline $\begin{array}{l}\text { Days after } \\
\text { inoculation }\end{array}$ & $\begin{array}{l}\text { No. of } \\
\text { mice }\end{array}$ & $\begin{array}{l}\text { Ceruloplasmin } \\
\text { Mean } \pm \text { S.E.M. }\end{array}$ & $t$-Test \\
\hline 4 & 9 & $19.7 \pm 1.3$ & $t 0.023, P>0.5$ \\
7 & 10 & $19.3 \pm 1.2$ & $t 0.048, P>0.5$ \\
10 & 8 & $13.5 \pm 0.6$ & $t 3.166, P<0.01$ \\
14 & 9 & $10.2 \pm 0.3$ & $t 5.202, P<0.001$ \\
Non-inoculated & & $19.2 \pm 1.7$ & \\
Controls & 16 & & \\
\hline
\end{tabular}

- $\mathrm{mg} / 100 \mathrm{ml}$ of serum. 'S.E.M., standard error of mean $=$ $\sqrt{\frac{\sum(x-\bar{x})^{2}}{n(n-1)}}$ the sera were separated and stored at $-15^{\circ} \mathrm{C}$. The maximum time of storage was $24 \mathrm{~h}$. Ceruloplasmin was determined enzymatically by the method of Ravin ${ }^{\text {? }}$, and values were expressed in $\mathrm{mg} / 100 \mathrm{ml}$ of serum. The significance of the differences between neoplasm bearing animals and control mice were statistically evaluated by the $t$-test ${ }^{8}$.

Results and discussion. From the results presented in the Table, it is clear that the neoplasm does not induce significant variations in serum ceruloplasmin levels up to the seventh day after inoculations. However, in more advanced stages (10 and 14 days post-inoculation) of Ehrlich carcinoma development statistically significant decreases of the enzyme were obtained.

The results of the experiments clearly show that the response of mice to the inoculation of Ehrlich carcinoma is different from that observed in human patients 1,2 with a variety of malignant tumors and in rats bearing experimental neoplasms ${ }^{4-6}$. It seems that the depression of the oxidase levels in mice secondary to the injection of Ehrlich carcinoma is a property of that tumor. In this connection it is interesting to remember that MAYER ${ }^{8}$ found Ehrlich tumor cells in the heart and blood vessels of liver, kidney and meninges of mice from 7 days onwards post-inoculation. Perhaps the presence of Ehrlich metastasis in the liver or the systemically circulating carcinoma cells interferes in some way with the synthesis of the enzyme, since low levels of serum ceruloplasmin were only seen in the advanced stages of evolution.

Résumé. On montre que la présence du carcinome d'Ehrlich provoque une diminution statistiquement significative des taux de la céruloplasmine sérique des souris aux dixième et quatorzième jours après l'inoculation.

\section{A. ABREU and R. R. ABREU 10}

Section of Biochemistry, Instituto Oswaldo Cruz, C.P. 926-ZC-00, Rio de Janeiro (Brasil), 10 June 1970.

1 J. F. Sullivan and K. T. Hart, J. Lab. clin. Med. 55, 260 (1960). 2 E. P. Pineda, H. A. Ravin and A. M. Rutenburg, Gastroenterology 43, 266 (1962).

3 W. J. P. NeISH, Experientia 15, 336 (1959).

4 E. Thomas and R. Constantinescu, Clin. chim. Acta 1.3, 708 (1966).

5 E. Thomas, R. Olinescu and R. Constantinescu, Clin. chim. Acta 73,711 (1966).

6 L. A. Abrev, Thesis (1961).

7 H. A. Ravin, J. Lab. clin. Med. 58, 161 (1961).

8 G. W. Snedecor, Statistical Methods (Iowa State College Press, Ames 1962).

${ }^{9}$ K. D. Mayer, Br. J. exp. Path. 47, 537 (1966).

10 One of us (R.R.A.) is working with a research grant from Conselho Nacional de Pesquisas (National Research Council of Brasil).

\section{The Thorium-Series in Cigarettes and in Lungs of Smokers}

From 1958 through 1965 W. V. MAYNEORD et al. ${ }^{1-3}$, using an $\alpha$-spectrometric method, carried out an extensive investigation about the level of the 2 natural radioactive series of thorium and radium occurring in man and his environment: soils, vegetation, animal tissues, human foods, drinking-water, human tissues. On this trend,
TURNER and RADLEY ${ }^{4}$ found ${ }^{226} \mathrm{Ra}$ and ${ }^{228} \mathrm{Ra}$ in all ashes of cigarette brands issued from around the whole world. Comparing the radon inhaled during smoking and that inhaled continuously with ambient air these authors concluded the first inhaled radioactivity must be negligible compared with the second one. Measuring ${ }^{210} \mathrm{Po}$ in 